\title{
ANALISIS TERHADAP TANDA BUKTI HAK ATAS TANAH BERDASARKAN UUPA DAN PERATURAN PEMERINTAH NOMOR 24 TAHUN 1997 TERKAIT PENGGUNAAN GIRIK NOMOR 87 PERSIL 157 KELURAHAN CENGKARENG BARAT (STUDI KASUS: PUTUSAN MAHKAMAH AGUNG NOMOR 2459K/PDT/2014)
}

\author{
Stella \\ (Mahasiswi Program S1 Fakultas Hukum Universitas Tarumanagara)
}

\begin{abstract}
Hasni
(Corresponding Author)

Dosen Hukum Agraria Universitas Trisaksti, Meraih Sarjana Hukum dari Fakultas Hukum UNKRIS Jakarta (1973), Magister Hukum dari Universitas Indonesia Jakarta (1986), dan Doktor Ilmu Hukum dari Universitas Trisakti (2012)
\end{abstract}

\begin{abstract}
Since of Agrarian Law in Indonesia, western right land and communal right land have been converted into land right according to Agrarian Law so the state is obliged to provide legal assurance through land registration, with the end product is certificate as a proof of title. Proof is an important part of law society as it is the legal standing of land ownership. A strong proof of title is defined in the Agrarian Law and Government Regulation as the implementing regulation, however Indonesian society especially low-economy society still the old proof of title. The main issue is how Customary Title Status relates to the proof of land right in the national land law and judge of Supreme Court made in consideration in resolving civil dispute number 2459K/Pdt/2014 on use of customary land title no.87 land parcel 157 West Cengkareng urban village. Based on the research outcome, that the existence of customary land title is still recognized to this date only as one of the requirements in the land registration process to prove the old title and conversion of communal land so that decision of Supreme Court is correctly made that customary land title is not a form of land ownership since there is no agency except National Land Agency can issue proof of title that is certificate. As of the result of this, certificate is a strong proof of land title. So should, there is an importance common understanding of customary land title from fiscal cadaster rather than legal cadaster.
\end{abstract}

Keywords: Proof, Land Right, Customary Title Status. 


\section{PENDAHULUAN}

\section{A. Latar belakang}

Tanah mempunyai peranan yang besar dalam pembangunan, adapun pengaturan mengenai pertanahan di Indonesia yang disebut dengan hukum agraria. Sebelum tahun 1960, di Indonesia berlaku dualisme hukum pertanahan. Disatu sisi berlaku hukum-hukum tanah hak kolonial belanda, tanah yang tunduk dan diatur Hukum Perdata Barat yang sering disebut Tanah Barat atau Tanah Eropa misalnya tanah hak eigendom, hak opstal, hak erfpacht dan lain-lainnya. ${ }^{1}$

Penguasaan tanah dengan hak penduduk asli atau bumi putera yang tunduk pada Hukum Adat yang tidak mempunyai bukti tertulis, yang dipunyai penduduk setempat sering disebut tanah adat misalnya tanah hak ulayat, tanah milik adat, tanah Yasan, tanah gogolan dan lainnya. ${ }^{2}$

Dualisme dalam hukum tanah bukan disebabkan karena para pemegang hak atas tanah melainkan karena perbedaan hukum yang berlaku terhadap tanahnya ${ }^{3}$, maka hal tersebut bertentangan dengan konsepsi yang mendasari hukum tanah nasional yang tersirat dalam sila-sila pancasila. Sehingga perlu dihapuskan dan diganti dengan undang-undang pokok agraria serta peraturan-peraturan agraria yang baru, yang lebih mengarah kepada hukum nasional berdasarkan Pancasila dan Undang-Undang Dasar Negara Republik Indonesia 1945 yang selanjutnya disebut UUD 1945.

Dalam Pasal 33 Ayat (3) amandemen ke-4 Undang-Undang Dasar Negara Republik Indonesia Tahun 1945 telah ditentukan bahwa: "Bumi dan air dan kekayaan alam yang terkandung di dalamnya dikuasai oleh negara dan dipergunakan untuk sebesar-besar kemakmuran rakyat”.

${ }^{1}$ Ulfia Hasanah, "Status Kepemilikan Tanah Hasil Konversi Hak Barat Berdasarkan UU No.5 Tahun 1960 Tentang Peraturan Dasar Pokok-Pokok Agraria Dihubungkan Dengan PP No.24 Tahun 1997 Tentang Pendaftaran Tanah”, Jurnal Ilmu Hukum, Volume.3, Nomor 1, (Juni 2005): 2 .

${ }^{2}$ Ibid., 2 .

${ }^{3}$ Boedi Harsono, Hukum Agraria Indonesia, Sejarah Pembentukan Undang-Undang Pokok Agraria, Isi Dan Pelaksanaannya, Cetakan ke-1, (Jakarta: Universitas Trisakti, 2013), 53. 
Realisasi dari Pasal 33 Ayat (3) UUD 1945, maka selanjutnya ketentuan mengenai bumi, air dan kekayaan alam diatur dalam UndangUndang Republik Indonesia Nomor 5 Tahun 1960 tentang Peraturan Dasar Pokok-Pokok Agraria yang selanjutnya disebut UUPA. ${ }^{4}$

Sejak berlakunya UUPA pada tanggal 24 September 1960 di Indonesia, ada tanah-tanah dengan hak-hak barat, seperti hak eigendom, hak erfpacht, hak opstal, yang disebut tanah-tanah hak barat atau tanah-tanah Eropa. Ada tanah-tanah dengan hak-hak Indonesia, seperti tanah-tanah dengan hak adat yang disebut tanah-tanah hak adat. ${ }^{5}$ Telah di konversi (diubah) menjadi hak atas tanah menurut UUPA.

Pengakuan negara terhadap hak atas tanah yang dimiliki orang atau badan hukum yang menimbulkan penguasaan atas tanah, membuat negara berkewajiban untuk memberikan jaminan kepastian hukum terhadap hak atas tanah tersebut. Hal itu dilakukan agar setiap orang atau badan hukum dapat mempertahankan haknya.

Pemerintah selaku badan pelaksana kegiatan negara, mengadakan pendaftaran tanah. Pendaftaran tanah dimaksudkan untuk memberikan kepastian dan perlindungan hukum akan hak atas tanah, sehingga tanda bukti yang kuat telah diatur dalam UUPA dan Peraturan Pemerintah No.24 Tahun 1997 yang selanjutnya disebut PP, yaitu produk akhir pendaftaran tanah adalah sertifikat hak atas tanah. Sertifikat berfungsi sebagai alat pembuktian yang kuat dalam bukti kepemilikan. ${ }^{6}$

Sebelum diterbitkannya sertifikat hak atas tanah melalui kegiatan pendaftaran tanah untuk pertama kali, yang meliputi pengumpulan dan

\footnotetext{
${ }^{4}$ Adelia Astrid, Skripsi: "Pendaftaran Pertama Kali Untuk Konversi Tanah Hak Milik Karena Pewarisan Melalui Kegiatan Layanan Rakyat Untuk Sertipikasi tanah (Larasita) Dalam Rangka Mewujudkan Tertib Administrasi Pertanahan Berdasarkan PP Nomor 24 Tahun 1997 Juncto Peraturan Kepala BPN Nomor 18 Tahun 2009 Di Kabupaten Boyolali”, (Yogyakarta: UAJY, 2011): 2.

${ }^{5}$ Boedi Harsono, Op.Cit., 53.

${ }^{6}$ Sri Handayani dan Pius Tri Wahyudi Soehartono, "Pendaftaran Hak Atas Tanah Letter C, Girik dan Petuk D Sebagai Alat Bukti Permulaan Di Kabupaten Sleman Daerah Istimewa Yogyakarta”, Jurnal Repertorium, Edisi No.2 Tahun 2015, 127.
} 
pengelolaan data fisik, pengumpulan dan pengolahan data yuridis serta pembukuan haknya, penerbitan sertifikat, penyajian data fisik dan data yuridis, penyimpanan daftar umum dan dokumen. ${ }^{7}$

Ada suatu kegiatan penting yaitu mengenai pengumpulan dan pengolahan data yuridis serta pembukuan haknya berupa perbedaan antara pembuktian hak-hak baru dan hak lama. Untuk pembuktian hak-hak atas tanah yang berasal dari konversi hak-hak lama, data yuridisnya dibuktikan dengan alat-alat bukti mengenai adanya hak tersebut berupa bukti tertulis, keterangan saksi, dan atau pernyataan yang bersangkutan yang kadar kebenaranya oleh Panitia Ajudikasi/Kepala Kantor Pertanahan dianggap cukup sebagai dasar untuk mendaftar hak, pemegang hak dan hak-hak pihak lain yang membebaninya. Demikianlah ditetapkan dalam Pasal 24 ayat (1) Peraturan Pemerintah No.24 Tahun 1997.

Alat-alat bukti tersebut adalah bukti-bukti pemilikan, dalam hal penegasan konversi hak yang lama menjadi hak baru yang didaftar, maka ada beberapa alat bukti tertulis yang dimaksudkan dalam penjelasan Pasal 24 ayat (1) yaitu salah satunya adalah petuk pajak bumi/Landrete, girik, pipil, kekitir, dan Verponding Indonesia sebelum berlakunya Peraturan Pemerintah 10/1961.

Pada masa saat ini, masih ada masyarakat di daerah perkotaan yang memiliki tanah hanya dengan berupa surat girik. Umumnya masyarakat masih berkeyakinan bahwa surat girik adalah sebagai tanda bukti hak atas tanah sehingga masyarakat sudah merasa aman jika hanya memiliki surat girik.

Hal ini menunjukan bahwa pada kenyataannya, kegiatan pendaftaran tanah belum dilaksanakan secara optimal di kalangan masyarakat, sehingga masih menimbulkan terjadinya gugatan melalui lembaga peradilan yang ditimbulkan oleh surat girik yang membuat adanya masing-masing

\footnotetext{
${ }^{7}$ Boedi Harsono, Hukum Agraria Indonesia, Sejarah Pembentukan Undang-Undang Pokok Agraria, Isi Dan Pelaksanaannya, Cetakan ke-1, (Jakarta: Universitas Trisakti, 2013), 487.
} 
perbedaan pendapat berupa pertimbangan yang dilakukan oleh hakim terkait dengan penggunaan surat girik.

Pada kenyataannya terdapat kasus yang menarik, seperti yang terjadi pada contoh kasus di dalam putusan Mahkamah Agung No.2459 K/PDT/2014, yaitu Dedy Firmansyah selaku Penggugat yang menjadi ahli waris dari alm.Hapas Haris selaku ayah dari Penggugat yang telah meninggal dunia, kasus ini bermula dari Penggugat yang memiliki sebidang tanah berdasarkan surat girik garapan no. 87 persil 157 S.II seluas 27.836 m2 yang beralamat di Kampung Rawa Bengkel RT 002/07 Kelurahan Cengkareng Barat, Kecamatan Cengkareng Jakarta Barat.

Masalah timbul pada saat bulan Februari 2013, Penggugat mengajukan gugatan terhadap PT Titu Harmoni selaku Tergugat I dan Walikotamadya Jakarta Barat cq. Camat Kecamatan Cengkareng cq. Lurah Kelurahan Cengkareng Barat selaku Tergugat II kepada Pengadilan Negeri Jakarta Barat atas dasar gugatan perbuatan melawan hukum karena Tergugat I telah melakukan penyerobotan dan pengerukan tanah yang dimiliki oleh Penggugat dan tanpa ijin dari Penggugat seluas $5.220 \mathrm{~m} 2$ untuk membuka jalan umum serta saluran air makro menuju jalan Ring Road dari Perumahan Taman Palem Asri.

Kemudian, Penggugat telah meminta bantuan Tegugat II untuk menghentikan segala kegiatan yang dilakukan oleh Tergugat I melalui surat tanggal 7 Februari 2013, namun tidak ada tindakan nyata dari Tergugat II untuk menghentikan penyerobotan tersebut bahkan terkesan adanya pembiaran dari Tergugat II.

Pada saat itu, Penggugat juga telah membuktikan dalil gugatannya dengan mengajukan fotocopy surat girik nomor 87 persil 157 S.II a/n Almarhum Hapas Haris, fotocopy surat keterangan lurah Cengkareng Barat nomor 233/1.711.2 tanggal 3 April 2012 dan Peta Ipeda tahun 1972, serta beberapa surat lainnya dan selain mengajukan surat bukti tersebut yang dapat ditunjukkan aslinya di pengadilan, Penggugat telah mengajukan 4 
orang saksi yang telah memberikan keterangan dibawah sumpah menurut agamanya dipersidangan.

Dalam gugatannya Penggugat meminta kepada Pengadilan Negeri Jakarta Barat agar menyatakan tanah yang beralamat di Kampung Rawa Bengkel RT 002/07 Kelurahan Cengkareng Barat, Kecamatan Cengkareng Jakarta Barat adalah sah secara hukum milik Penggugat berdasarkan surat girik nomor 87 Persil 157 S.II dan menyatakan secara hukum para Tergugat bersalah melakukan perbuatan melawan hukum serta memerintahkan kepada Tergugat II untuk melakukan tindakan nyata dengan memerintahkan kepada Tergugat I menghentikan seluruh kegiatannya diatas tanah milik Penggugat serta menghukum Tergugat I untuk membayar ganti kerugian materiil dan immateril kepada Penggugat sebesar Rp 29.666.000.000,00.

Berdasarkan putusan Pengadilan Negeri Jakarta Barat, Hakim mengabulkan gugatan Penggugat sebagian dengan menyatakan Tergugat I dan Tergugat II terbukti telah melakukan perbuatan melawan hukum serta menyatakan secara hukum tanah yang beralamat di Kampung Rawa Bengkel RT 002/07 Kelurahan Cengkareng Barat, Kecamatan Cengkareng Jakarta Barat seluas $22.616 \mathrm{~m} 2$ adalah sah secara hukum milik Penggugat berdasarkan surat girik nomor 87 Persil 157 S.II. Tetapi menghukum Tergugat I mengganti kerugian materiil kepada Penggugat hanya sebesar Rp 10.044.000.000,00. ${ }^{8}$

Hakim Pengadilan Negeri Jakarta Barat mengabulkan gugatan Penggugat dengan beberapa pertimbangan yaitu salah satunya adalah surat yang diajukan oleh Penggugat diperkuat dengan adanya keterangan saksisaksi maka terdapat fakta bahwa Penggugat adalah pemilik sebidang tanah dengan seluas $27.836 \mathrm{~m} 2$ berdasarkan surat girik nomor 87 Persil 157 S.II yang beralamat di Kampung Rawa Bengkel RT 002/07 Kelurahan Cengkareng Barat, Kecamatan Cengkareng Jakarta Barat.

${ }^{8}$ Putusan Pengadilan Negeri Jakarta Barat Nomor 210/Pdt.G/2013/PN.JKT.BAR, 37. 
Hasil putusan Pengadilan Negeri Jakarta Barat tersebut, menimbulkan pihak Tergugat I melakukan banding kepada Pengadilan Tinggi Jakarta. Kemudian Pengadilan Tinggi Jakarta telah membuat amar putusan menyatakan bahwa menguatkan putusan Pengadilan Negeri Jakarta Barat nomor 210/Pdt.G/2013/PN.JKT.BAR. dengan pertimbangan yang menyatakan, hakim Pengadilan Negeri Jakarta Barat sudah benar dalam menerapkan hukum dengan menyatakan pihak Terbanding/Penggugat adalah pemilik tanah yang sah dalam perkara aquo dan sudah benar dalam menerapkan hukum bahwa Pembanding/Tergugat I telah melakukan penyerobotan tanah milik Terbanding/Penggugat. Namun, putusan Pengadilan Negeri Jakarta Barat yang dikuatkan dengan adanya perbaikan pertimbangan besarnya ganti rugi materiil harusnya sebesar Rp 5.220.000.000,- bukan Rp 10.044.000.000,- . 9

Kemudian hasil putusan Pengadilan Tinggi Jakarta tersebut, menimbulkan pihak Pembanding/Tergugat I mengajukan kasasi kepada Mahkamah Agung. Kemudian, berdasarkan Putusan No.2459 K/Pdt/2014, Hakim menyatakan membatalkan Putusan Pengadilan Tinggi Jakarta No.223/Pdt/2014/PT DKI yang memperbaiki Putusan Pengadilan Negeri Jakarta Barat No.210/Pdt.G/2013/PN.JKT.BAR serta mengadili sendiri yaitu menolak gugatan Penggugat seluruhnya dan juga menyatakan eksepsi Tergugat I tidak dapat diterima.

Pertimbangannya antara lain adalah pihak Penggugat sekarang Termohon Kasasi tidak memiliki bukti kepemilikan atas tanah perkara yaitu Sertifikat Hak Milik. Oleh karena itu, perbuatan Tergugat I membuka jalan umum serta saluran air makro menuju jalan Ring Road dari Perumahan Taman Palem Asri dan terkait Tergugat II, lurah kelurahan Cengkareng Barat tidak melarang pembuatan jalan dan saluran air dimaksud maka perbuatan tersebut bukan merupakan perbuatan melawan hukum. ${ }^{10}$

\footnotetext{
${ }^{9}$ Putusan Pengadilan Tinggi DKI Nomor 223/PDT/2014/PT.DKI, 6.

${ }^{10}$ Putusan Mahkamah Agung Nomor 2459 K/PDT/2014, 23.
} 
Dari uraian di atas maka penulis tertarik untuk meneliti mengenai “Analisis Terhadap Tanda Bukti Hak Atas Tanah Berdasarkan UUPA dan Peraturan Pemerintah No.24 Tahun 1997 Terkait Penggunaan Girik No.87 Persil 157 Kelurahan Cengkareng Barat (Studi Kasus: Putusan Mahkamah Agung Nomor 2459K/Pdt/2014)".

\section{B. Perumusan Masalah}

1. Bagaimana status girik terkait pembuktian hak atas tanah dalam hukum tanah nasional ?

2. Bagaimana pertimbangan hakim Mahkamah Agung dalam memutus perkara sengketa perdata nomor $2459 \mathrm{~K} / \mathrm{Pdt} / 2014$ terkait penggunaan girik no.87 persil 157 Kelurahan Cengkareng Barat?

\section{PEMBAHASAN}

A. Status girik terkait pembuktian hak atas tanah dalam hukum tanah nasional

Hak atas tanah adalah hak yang memberi wewenang kepada yang mempunyai hak untuk menggunakan atau mengambil manfaat dari tanah yang dihakinya. ${ }^{11}$ Setiap hak atas tanah mempunyai fungsi sosial artinya setiap hak atas tanah tidak saja memberi wewenang bagi pemegang haknya tetapi juga memberi kewajiban untuk menggunakan tanahnya yang dikuasainya pada batas-batas sesuatu dengan memperhatikan kepentingan umum atau dengan perkataan lain tanah tersebut tidak boleh diterlantarkan. $^{12}$

Adapula pengelompokan hak-hak atas tanah dalam 2 kelompok, yaitu hak-hak atas tanah primer dan hak-hak atas tanah sekunder. Hak-hak atas tanah primer adalah adalah hak-hak yang diberikan oleh negara. Hakhak atas tanah sekunder adalah yang bersumber pada hak pihak lain. ${ }^{13}$

${ }^{11}$ Urip Santoso, Pendaftaran dan Peralihan Hak Atas Tanah, Cetakan ke-1, (Jakarta: Kencana, 2010), 49.

${ }^{12}$ Abdurahman dan Arie Sukamti, Tanya Jawab Masalah Pertanahan, Cetakan ke-1, (Jakarta: Sinar Harapan, 1985), 22.

${ }^{13}$ Boedi Harsono, Hukum Agraria Indonesia, Sejarah Pembentukan Undang-Undang Pokok Agraria, Isi Dan Pelaksanaannya, Cetakan ke-1, (Jakarta: Universitas Trisakti, 2013), 288. 
Khusus mengenai hak-hak atas tanah primer, akan diuraikan definisi sebagai berikut:

1. Hak milik atas tanah dalam pengertian sekarang, sebagaimana tercantum dalam Pasal 20 Ayat (1) UUPA adalah sebagai berikut: "Hak milik adalah hak turun-temurun, terkuat dan terpenuh yang dapat dipunyai orang atas tanah, dengan mengingat ketentuan dalam pasal 6." ${ }^{\prime 14}$ Dijelaskan dalam penjelasan pasal tersebut, bahwa maksud penyataan "terkuat dan terpenuh" adalah untuk menunjukkan bahwa di antara hak-hak atas tanah, hak miliklah yang ter-(“dalam arti paling”) kuat dan “ter"-penuh yaitu mengenai tidak adanya batas waktu penguasaan tanahnya dan luas limgkup penggunaannya, yang meliputi baik untuk diusahakan ataupun digunakan sebagai tempat membangun sesuatu. Terjadinya hak milik sebagaimana diatur dalam Pasal 22 Ayat (1) UUPA menurut hukum adat diatur dengan Peraturan Pemerintah dan ayat 2 menyatakan selain menurut cara sebagai yang dimaksud dalam ayat 1 , hak milik terjadi karena penetapan pemerintah, menurut cara dan syarat-syarat yang ditetapkan dengan Peraturan Pemerintah serta ketentuan undang-undang.

2. Hak Guna Usaha dalam pengertian sekarang, sebagaimana tercantum dalam Pasal 28 Ayat (1) UUPA adalah sebagai berikut: "hak untuk mengusahakan tanah yang dikuasai langsung oleh Negara, dalam jangka waktu sebagaimana tersebut dalam Pasal 29, guna perusahaan pertanian, perikanan, atau peternakan." ${ }^{15}$ Hak Guna Usaha diberikan untuk jangka

${ }^{14}$ Eddy Ruchiyat, Politik Pertanahan Nasional Sampai Orde Reformasi, Cetakan ke-3, (Bandung: PT Alumni, 2006), hal.45.

${ }^{15}$ Eddy Ruchiyat, Politik Pertanahan Sebelum dan Sesudah Berlakunya UUPA, Cetakan ke-1, (Bandung: Alumni, 1984), hal. 52. 
waktu 25 tahun (Pasal 29 Ayat (1) UUPA) tetapi untuk perusahaan membutuhkan waktu lebih lama maka dapat diberikan Hak Guna Usaha untuk waktu paling lama 35 tahun (Pasal 29 Ayat (2) UUPA) dan dapat diperpanjang untuk jangka waktu paling lama 25 tahun (Pasal 29 Ayat (3) UUPA). Tanah yang dapat diberikan dengan Hak Guna Usaha memiliki luas minimum tanah adalah 5 hektar (Pasal 28 Ayat (2) UUPA) serta luas maksimum tanah yang dapat diberikan Hak Guna Usaha adalah 25 hektar (Pasal 28 Ayat (2) UUPA).

3. Pengertian Hak Guna Bangunan diatur dalam Pasal 35 UUPA, yaitu hak untuk mendirikan dan mempunyai bangunanbangunan atas tanah yang bukan miliknya sendiri, dengan jangka waktu paling lama 30 tahun. Jangka waktu Hak Guna Bangunan atas tanah yang bukan mililknya sendiri yaitu waktu paling lama 30 tahun (Pasal 35 Ayat (1) UUPA) dan dapat diperpanjang untuk jangka waktu paling lama 20 tahun (Pasal 35 Ayat (2) UUPA). Hak Guna Bangunan terjadi mengenai tanah yang dikuasai langsung oleh Negara: karena penetapan pemerintah (Pasal 37 UUPA huruf a) dan mengenai tanah milik: karena perjanjian yang berbentuk otentik antara pemilik tanah yang bersangkutan dengan pihak yang akan memperoleh Hak Guna Bangunan itu, yang bermaksud menimbulkan hak tersebut (Pasal 37 UUPA huruf b).

4. Pengertian Hak Pakai diatur dalam Pasal 41 Ayat (1) UUPA yaitu hak untuk menggunakan dan/atau memungut hasil dari tanah yang dikuasai langsung oleh Negara atau tanah milik orang lain, yang memberi wewenang dan kewajiban yang ditentukan dalam keputusan pemberiannya oleh pejabat yang berwenang memberikannya atau dalam perjanjian dengan pemilik tanahnya, yang bukan perjanjian sewa menyewa atau 
perjanjian pengolahan tanah, segala sesuatu asal tidak bertentangan dengan jiwa dan ketentuan undang-undang ini.

Adanya hak-hak atas tanah tersebut, maka diperlukan suatu jaminan kepastian hukum di bidang pertanahan. Pemberian jaminan kepastian hukum di bidang pertanahan memerlukan:

a. Tersedianya perangkat hukum tertulis yang lengkap dan jelas serta dilaksanakan secara konsisten;

b. Penyelenggaraan pendaftaran tanah yang efektif. ${ }^{16}$

Dengan tersedianya perangkat hukum yang tertulis, siapa pun yang berkepentingan akan dengan mudah mengetahui kemungkinan apa yang tersedia baginya untuk menguasai dan menggunakan tanah yang diperlukannya, bagaimana cara memperolehnya, hak-hak, kewajiban serta larangan apa yang ada dalam menguasai tanah dengan hak-hak tertentu, sanksi apa yang dihadapinya jika diabaikan ketentuan-ketentuan yang bersangkutan serta hal-hal lain yang berhubungan dengan penguasaan dan penggunaan tanah yang dipunyainya. ${ }^{17}$

Bagi tanah-tanah hak Barat tersedia hukum yang tertulis dan lengkap, terkodifikasi dalam suatu kitab Undang-Undang yang mudah diperoleh. Tetapi sebagian besar tanah yang dipunyai dengan hak-hak adat, hukumnya tidak tertulis, hingga tidak mudah diketahui isinya, khususnya bagi orang-orang "luar" masyarakat hukum adat yang bersangkutan. ${ }^{18}$

Ketentuan-ketentuan hukum Tanah Administratif hampir semuanya merupakan hukum yang tertulis, tetapi jumlahnya amat banyak, dalam berbagai bentuk peraturan perundang-undangan tersebar tetapi tidak terkodifikasi. Ada yang berlaku untuk seluruh wilayah Hindia Belanda, ada yang untuk wilayah atau daerah tertentu saja. Bahkan ada pula yang

${ }^{16}$ Boedi Harsono, Hukum Agraria Indonesia, Sejarah Pembentukan Undang-Undang Pokok Agraria, Isi Dan Pelaksanaannya, Cetakan ke-1, (Jakarta: Universitas Trisakti, 2013), 69.

${ }^{17}$ Ibid.,

${ }^{18}$ Ibid., 
disediakan untuk golongan rakyat tertentu saja. ${ }^{19}$ Demikianlah maka Hukum Tanah yang tersedia, baik Hukum Perdata maupun Hukum Tanah Administratif belum cukup memberikan jaminan kepastian hukum, terutama bagi rakyat pribumi. ${ }^{20}$

Di bidang-bidang hukum yang lain, tersedianya perangkat hukum tertulis yang lengkap, jelas, dan mudah diketahui ketentuan-ketentuannya serta yang dilaksanakannya secara konsisten oleh para petugas pelaksana, pengadilan dan masyarakat sendiri, semuanya sudah cukup untuk menjamin terwujudnya kepastian hukum di bidang yang bersangkutan. Tetapi di bidang pertanahan, dalam menghadapi kasus-kasus konkret, pemberian jaminan kepastian hukum belum dapat diwujudkan hanya dengan tersedianya perangkat hukum yang memenuhi persyaratan yang dimaksudkan diatas. ${ }^{21}$

Keterangan yang dimaksudkan itu tidak mungkin diperoleh dari perangkat perundang-undangan yang tersedia. Untuk itu, diperlukan penyelenggaraan kegiatan yang disebut pendaftaran tanah yang merupakan suatu legal cadaster atau suatu kepastian hukum dan kepastian hak di bidang pertanahan. ${ }^{22}$

Dalam UUPA, mengenai pendaftaran ini diatur dalam pasal 19 sebagai berikut:

Pasal 19 (1): "Untuk menjamin kepastian hukum oleh pemerintah diadakan pendaftaran tanah di seluruh wilayah Republik Indonesia menurut ketentuan-ketentuan yang diatur dengan peraturan pemerintah.

Pasal 19 (2): "Pendaftaran tersebut dalam ayat 1 pasal ini meliputi:

a. Pengukuran, perpetaan, dan pembukuan tanah;

b. Pendaftaran hak-hak atas tanah dan peralihan hak-hak tersebut;

\footnotetext{
${ }^{19}$ Ibid.,

${ }^{20}$ Ibid., 70.

${ }^{21}$ Ibid.,

${ }^{22}$ Ibid., 71.
} 
c. Pemberian surat-surat bukti, yang berlaku sebagai alat pembuktian yang kuat. ${ }^{23}$

Pasal 19 UUPA, yang ditujukan kepada pemerintah untuk melaksanakan pendaftaran tanah di seluruh wilayah Republik Indonesia, adalah merupakan kewajiban pemerintah sebagai penguasa tertinggi terhadap tanah. Sedangkan Pasal 23, 32, dan 38 UUPA, yang menyatakan bahwa Hak Milik, Hak Guna Usaha, dan Hak Guna Bangunan setiap peralihan, hapusnya, dan pembebanannya dengan hak-hak lain harus didaftarkan adalah merupakan "kewajiban" bagi yang mempunyai hak-hak tersebut, dengan maksud agar mereka mendapat kepastian hukum tentang haknya itu. ${ }^{24}$

Pengertian pendaftaran tanah menurut Pasal 1 Peraturan Pemerintah Nomor 24 tahun 1997 adalah:

"rangkaian kegiatan, yang dilakukan oleh Pemerintah secara terus menerus, berkesinambungan dan teratur, meliputi pengumpulan, pengolahan, pembukuan, dan penyajian serta pemeliharaan data fisik dan data yuridis dalam bentuk peta dan daftar, mengenai bidang-bidang tanah dan satuan-satuan rumah susun, termasuk pemberian surat tanda bukti haknya bagi bidang-bidang tanah yang sudah ada haknya dan hak milik atas satuan rumah susun serta hak-hak tertentu yang membebaninya."

Kegiatan pendaftaran tanah meliputi kegiatan pendaftaran tanah untuk pertama kali dan kegiatan pemeliharaan data. Pendaftaran tanah untuk pertama kali didasarkan melalui pendaftaran tanah secara sistematik dan pendaftaran tanah secara sporadik. Pendaftaran tanah secara sistematik dilaksanakan atas prakarsa Badan Pertanahan Nasional yang di dasarkan atas suatu rencana kerja jangka panjang dan rencana tahunan yang berkesinambungan, pelaksanaannya dilakukan di wilayah-wilayah yang ditunjuk oleh Menteri. Pendaftaran tanah secara sporadik dilaksanakan atas

${ }^{23}$ Y.W Sunindhia dan Ninik Widiyanti, Pembaharuan Hukum Agraria (Beberapa Pemikiran), Cetakan ke-1, (Jakarta: PT Bina Aksara, 1988), 137.

${ }^{24}$ K Wantjik Saleh, Hak Anda Atas Tanah, Cetakan ke-3, (Jakarta Timur: Balai Aksara, 1980), 61-62. 
permintaan pihak yang berkepentingan, yaitu pihak berhak atas obyek pendaftaran tanah yang bersangkutan. ${ }^{25}$

Kegiatan pemeliharaan data adalah data yang disimpan/disajikan, baik data fisik maupun data yuridis, perlu disesuaikan dengan perubahanperubahan yang terjadi kemudian, agar selalu sesuai dengan keadaan yang sebenarnya. Perubahan data fisik terjadi jika luas tanahnya berubah, yaitu jika terjadi pemisahan atau pemecahan bidang tanah yang bersangkutan menjadi satuan-satuan baru atau penggabungan bidang-bidang tanah yang berbatasan menjadi satuan-satuan persil.

Produk akhir kegiatan pendaftaran tanah berupa sertifikat hak atas tanah, mempunyai banyak fungsi bagi pemiliknya, dan fungsinya itu tidak dapat digantikan dengan benda lain. ${ }^{26}$ Fungsi utama sertifikat hak atas tanah adalah sebagai alat bukti, tetapi sertifikat bukan satu-satunya alat bukti hak atas tanah. Hak atas tanah seseorang masih mungkin dibuktikan dengan alat bukti lain, misalnya saksi-saksi, akta jual beli, surat keputusan pemberian hak. ${ }^{27}$ Namun demikian, sertifikat merupakan alat bukti yang kuat, berarti keterangan-keterangan yang ada di dalamnya dianggap benar selama tidak dibuktikan sebaliknya. ${ }^{28}$

Dalam hukum tanah sekarang, pembuktian hak atas tanah merupakan hasil penyelenggaraan pendaftaran tanah yang dilaksanakan dalam rangka legal cadaster dengan tujuan untuk menciptakan kepastian hukum dan kepastian hak (Pasal 19 Ayat (1) UUPA), pendaftaran semacam ini disebut dengan rechkadaster. Pasal 19 Ayat (1) UUPA menegaskan seperti itu karena ada pendaftaran lain yang tujuannya bukan untuk kepastian hukum tetapi hanya untuk mempermudah pemungutan pajak

${ }^{25}$ Boedi, Op.Cit., 487.

${ }^{26}$ Adrian Sutedi, Sertifikat Hak Atas Tanah, Cetakan ke-3, (Jakarta: Sinar Grafika, 2014), hal. 57.

${ }^{27}$ Effendi Perangin, Praktek Pengurusan Sertifikat Hak Atas Tanah, Cetakan ke-2, (Jakarta: Rajawali Pers, 1990), hal. 1.

${ }^{28}$ Abdurahman dan Arie Sukamti, Tanya Jawab Masalah Pertanahan, Cetakan ke-1, (Jakarta: Sinar Harapan, 1985), hal. 81. 
tanah. Itulah yang disebut dengan fiscal cadaster. Hasil fiscal cadaster diantaranya berbentuk girik, verponding Indonesia, verponding Eropa yang bukan merupakan tanda bukti hak.

Penyelenggaraan pendaftaran sekarang ini yang menghasilkan tanda bukti hak seperti yang dimaksud dalam Pasal 19 UUPA dan PP No.10 Tahun 1961 yang sudah diganti dengan PP No.24 Tahun 1997 merupakan kegiatan pendaftaran dalam legal cadaster dengan hasil akhirnya adalah tanda bukti kuat yang dinamakan sertipikat (Pasal 19 Ayat (2) huruf c UUPA). Menurut Boedi Harsono, girik, petuk pajak, dan pipil yang fungsinya sebagai surat pengenaan dan tanda pembayaran pajak, di kalangan rakyat dianggap dan diperlakukan sebagai tanda-tanda bukti pemilikan tanah yang bersangkutan. ${ }^{29}$

Menurut Peraturan Pemerintah No.24 Tahun 1997, khususnya Pasal 24 yang memuat berbagai petunjuk yang dapat dijadikan warkah untuk penerbitan sertifikat, ternyata girik merupakan salah satu warkah yang dapat dijadikan dasar untuk penerbitan sertifikat. Sudah tentu harus ditambah dengan petunjuk lain yang memperkuat kedudukan orang yang namanya tercantum dalam girik.

Mengenai untuk jelasnya, dibawah ini dikutip penjelasan Pasal 24 Ayat (1) Peraturan Pemerintah No.24 Tahun 1997 yaitu bukti kepemilikan itu pada dasarnya terdiri dari bukti kepemilikan atas nama pemegang hak pada waktu berlakunya UUPA dan apabila hak tersebut kemudian beralih, bukti peralihan hak berturut-turut sampai ke tangan pemegang hak pada waktu dilakukan pembukuan hak. Alat-alat bukti tertulis yang dimaksudkan dapat berupa:

1) Grosse akta hak eigendom yang diterbitkan berdasarkan Overschrijvings Ordonnantie (Staatsblad 1834-27), yang telah dibubuhi catatan, bahwa hak eigendom yang bersangkutan dikonversi menjadi Hak Milik;

29 Adrian Sutedi, Peralihan Hak Atas Tanah Dan Pendaftarannya, Cetakan ke-4, (Jakarta: Sinar Grafika, 2010), 41. 
2) Grosse akta hak eigendom yag diterbitkan berdasarkan Ordonantie tersebut sejak berlakunya UUPA sampai tanggal pendaftaran tanah dilaksanakan menurut PP 10/1961 di daerah yang bersangkutan;

3) Surat tanda bukti Hak Milik yang diterbitkan berdasarkan Peraturan Swapraja yang bersangkutan;

4) Sertifikat Hak Milik yang diterbitkan berdasarkan Peraturan Menteri Agraria No.9 Tahun 1959;

5) Surat keputusan pemberian hak milik dari pejabat yang berwenang, baik sebelum atau sejak berlakunya UUPA, yang tidak disertai kewajiban untuk mendaftarkan hak yang diberikan, tetapi telah dipenuhi semua kewajiban yang disebut di dalamnya;

6) Akta pemindahan hak yang dibuat dibawah tangan, yang dibubuhi tanda kesaksian oleh Kepala Adat/Kepala Desa/Kelurahan, yang dibuat sebelum berlakunya PP ini. Ini merupakan perubahan pasal 19 PP 10/1961, yang menentukan, bahwa harus ada bukti akta PPAT, sejak PP tersebut mulai dilaksanakan di suatu daerah;

7) Akta pemindahan hak atas tanah yang dibuat oleh PPAT, yang tanahnya belum dibukukan;

8) Akta ikrar wakaf/surat ikrar wakaf yang dibuat sebelum atau sejak mulai dilaksanakan Peraturan Pemerintah Nomor 28 Tahun 1977;

9) Risalah lelang yang dibuat oleh Pejabat Lelang yang berwenang, yang tanahnya belum dibukukan;

10) Surat penunjukan atau pembelian kaveling tanah pengganti tanah yang diambil oleh Pemerintah/Pemerintah Daerah;

11) Petuk Pajak Bumi/Landrete, girik, pipil, kekitir dan Verponding Indonesia sebelum berlakunya PP 10/1961; 
12) Surat keterangan riwayat tanah yang pernah dibuat oleh Kantor Pelayanan Pajak Bumi dan Bangunan;

13) Lain-lain bentuk alat pembuktian tertulis dengan nama apapun juga sebagaimana dimaksud dalam Pasal II, VI, dan VII Ketentuan-ketentuan Konversi UUPA.

Dalam hal bukti tertulis tersebut tidak lengkap atau tidak ada lagi, pembuktian kepemilikan itu dapat dilakukan dengan keterangan saksi atau pernyataan yang bersangkutan yang dapat dipercaya kebenarannya menurut pendapat Panitia Ajudikasi dalam pendaftaran tanah secara sistematik atau oleh Kepala Kantor Pertanahan dalam pendaftaran tanah secara sporadik. Yang dimaksud dengan saksi adalah orang yang cakap memberikan kesaksian dan mengetahui kepemilikan tersebut.

Berdasarkan Yurisprudensi Mahkamah Agung No. 34K/Sip/1960 tanggal 10 Februari 1960, Petuk pajak bumi tidak merupakan suatu bukti mutlak sebagai pemilik bagi orang yang namanya tercantum dalam petuk itu; ia hanya merupakan suatu tanda yang tentang siapakah yang harus membayar pajak. ${ }^{30}$

Petuk pajak istilah lain dari girik, istilah lain dari Verponding Indonesia bukan merupakan tanda bukti hak atas tanah yang dipersengketakan akan tetapi jika tidak ada bukti lain, girik dan sejenisnya dapat dipakai sebagai petunjuk. Bahwa orang yang namanya tercantum di girik itu merupakan pemegang hak atas tanah yang bersangkutan.

Maka, jelas bahwa girik bukan tanda bukti hak yang dari hasil pendaftaran legal cadaster dan girik tidak dianggap sebagai alat bukti kepemilikan tanah, melainkan girik tersebut merupakan wajib pajak bagi pemegangnya karena telah menggunakan dan mengambil hasil manfaat atas suatu bidang tanah.

Hal ini menunjukkan bahwa produk girik tersebut merupakan bukti surat pengenaan dan tanda pembayaran pajak yang diakui kalangan

30 Abdurahman, Himpunan Yurisprudensi Hukum Agraria, Seri Hukum Agraria VI, (Bandung: Alumni, 1980), 179. 
masyarakat sebagai tanda bukti kepemilkan tanah sebelum lahirnya UUPA karena pajaknya dikenakan pada yang memiliki tanahnya. Tetapi setelah lahirnya UUPA, girik sudah tidak lagi dibuat namun keberadaannya masih diakui sampai dengan saat ini. Keberadaan girik sampai dengan sekarang, memiliki fungsi sebagai salah satu syarat untuk pengkonversian tanah milik adat.

Konversi adalah perubahan hak yang lama menjadi satu hak yang baru menurut UUPA (Boedi Harsono 1968:140). Maka, dapat disimpulkan bahwa konversi hak-hak atas tanah adalah penggantian/perubahan hak-hak atas tanah dari status yang lama, yaitu sebelum berlakunya UUPA menjadi status yang baru, sebagaimana diatur menurut UUPA itu sendiri. ${ }^{31}$ Adapun yang dimaksud dengan hak-hak atas tanah sebelum berlakunya UUPA adalah hak-hak atas tanah yang diatur dan tunduk pada hukum adat dan hukum Barat (BW). ${ }^{32}$

Landasan hukum konversi terhadap hak-hak atas tanah yang ada sebelum berlakunya UUPA tanggal 24 September 1960 adalah bagian kedua dari UUPA, khususnya untuk tanah-tanah yang tunduk kepada hukum adat dan sejenisnya diatur dalam Pasal II, Pasal VI, dan Pasal VII ketentuanketentuan konversi, disamping itu untuk pelaksanaan konversi yang dimaksud oleh UUPA dipertegas lagi dengan dikeluarkannya Peraturan Menteri Pertanian Agraria Nomor 2 Tahun 1962 (selanjutnya disebut sebagai "PMPA") dan SK Menteri Dalam Negeri Nomor 26/DDA/1970. ${ }^{33}$

Dalam Pasal 3 PMPA mengatur tentang hak-hak yang tidak diuraikan dalam sesuatu surat hak atas tanah, maka oleh yang bersangkutan diajukan $^{34}$ :

a) Tanda bukti haknya, yaitu bukti surat pajak hasil bumi/verponding Indonesia atau bukti surat pemberian hak oleh

\footnotetext{
${ }^{31}$ Adrian Sutedi, Op.Cit., 125.

${ }^{32}$ Ibid.,

${ }^{33}$ Ibid., 128.

${ }^{34}$ Ibid.,
} 
instansi yang berwenang (kalau ada disertakan pula surat ukurnya).

b) Surat keterangan Kepala Desa yang dikuatkan oleh asisten Wedana (Camat) yang :

(1) Membenarkan surat atau surat bukti hak itu.

(2) Menerangkan apakah tanahnya tanah perumahan atau tanah pertanian.

(3) Menerangkan siapa yang mempunyai hak itu, kalau ada disertai turunan surat-surat jual beli tanahnya.

c) Tanda bukti kewarganegaraan yang sah dari yang mempunyai hak.

Dari ketentuan Pasal 3 diatas, maka khusus untuk tanah-tanah yang tunduk pada Hukum Adat, tetapi tidak terdaftar dalam ketentuan konversi sebagai tanah yang dapat dikonversikan kepada sesuatu hak atas tanah menurut ketentuan UUPA, tetapi diakui tanah tersebut sebagai hak adat, maka ditempuhlah dengan upaya "Penegasan Hak" yang diajukan kepada Kepala Kantor Pendaftaran Tanah setempat diikuti dengan bukti pendahuluan seperti bukti pajak, surat jual beli yang dilakukan sebelum berlakunya UUPA dan surat membenarkan tentang hak seseorang dan menerangkan juga tanah itu untuk perumahan atau untuk pertanian dan keterangan kewarganegaraan orang yang bersangkutan. ${ }^{35}$

Dalam Pasal 7 PMPA telah diatur lembaga konversi lain yang dinamakan "Pengakuan Hak", yaitu perlakuan atas tanah-tanah yang tidak ada atau tidak ada lagi tanda bukti haknya, maka yang bersangkutan dapat mengajukan permohonan kepada Kepala Kantor Wilayah Pertanahan setempat, permohonan tersebut diumumkan 2 bulan berturur-turut di kantor pendaftaran tanah dan kantor kecamatanl, jika tidak diterima dan keberatan, mereka membuat pernyataan keberatan tersebut kepada kantor BPN dan kemudian mengirimkannya kepada Kepala Kantor Wilayah Pertanian

${ }^{35}$ Ibid., 129. 
setempat, penerbitan pengakuan hak diberikan oleh Kepala Kantor Wilayah BPN, dari SK pengakuan hak tersebut sekaligus mempertegaskan hak apa yang diberikan/padanan pada permohonan tersebut, bisa saja hak milik, hak guna usaha, atau hak guna bangunan, atau hak pakai (A.P.Parlindungan, 1990:42). ${ }^{36}$

Pendaftaran tanah dilakukan baik secara sendiri (permohonan individu) maupun secara sistematik (massal) terhadap hak atas tanah yang tunduk pada hukum adat yang memiliki bukti, baik tertulis maupun tidak tertulis, sebelum didaftarkan harus dikonversi.

Girik sebagai surat pengenaan dan tanda pembayaran pajak dapat disertakan sebagai salah satu syarat proses pendaftaran tanah, khususnya dalam hal pembuktian hak lama, dibuktikan dengan alat-alat bukti tertulis mengenai adanya hak tersebut. Tetapi apabila dalam hal tidak ada lagi secara lengkap pembuktian tertulis, maka pembukuan hak dapat dilakukan berdasarkan penguasaan fisik bidang tanah selama 20 tahun atau lebih, demikian hal tersebut telah diatur dalam Peraturan Pemerintah No.24 Tahun 1997 yang tercantum dalam Pasal 24 Ayat (1) dan Ayat (2).

\section{B. Pertimbangan Hakim Mahkamah Agung Dalam Memutus Perkara Sengketa Perdata Nomor 2459K/Pdt/2014 Terkait Penggunaan Girik No.87 Persil 157 Kelurahan Cengkareng Barat}

Sebagaimana yang telah dijelaskan diatas, dalam Putusan Pengadilan Mahkamah Agung Nomor 2459K/Pdt/2014 bahwa Dedy Firmansyah selaku Penggugat sekarang Termohon Kasasi dan PT.Titu Harmoni selaku Tergugat I sekarang Pemohon Kasasi ditolak gugatannya secara keseluruhan oleh hakim Mahkamah Agung serta hakim Mahkamah Agung mengadili sendiri yaitu membatalkan Putusan Pengadilan Tinggi DKI yang telah memperbaiki amar Putusan Pengadilan Negeri Jakarta Barat.

Berdasarkan hasil pemeriksaan persidangan ternyata pihak Penggugat yang sekarang disebut Termohon Kasasi tidak memiliki bukti

${ }^{36}$ Ibid., 
kepemilikan atas tanah perkara berupa sertifikat hak milik, sedangkan surat Girik yang dimilikinya bukanlah surat bukti kepemilikan hak atas tanah sehingga perbuatan Tergugat I yang membuka jalan umum serta saluran air makro menuju jalan Ring Road dari perumahan Taman Palem Lestari dan juga perbuatan Tergugat II yang tidak melarang pembuatan jalan dan saluran air dimaksud bukan merupakan perbuatan melawan hukum.

Penggunaan girik yang terjadi pada contoh kasus ini, terkait dengan bahwa nama seseorang yang tercantum dalam girik dapat dijadikan sebagai petunjuk yang merupakan pemegang haknya karena pengenaan pajak dilakukan terhadap yang memiliki tanahnya. Sehingga pada putusan Pengadilan Negeri dan putusan Pengadilan Tinggi bahwa gugatan Penggugat dikabulkan karena hakim mengetahui bahwa girik memang bukan merupakan tanda bukti kepemilikan atas tanah dan hanya berupa tanda bukti pembayaran pajak tetapi wajib pajaknya merupakan pemilik tanah.

Kelemahan Penggugat sekarang Termohon Kasasi yaitu tidak dapat membuktikan haknya dengan tanda bukti yang kuat yang disebut dengan sertipikat. Mengingat yang dipunyai Termohon Kasasi hanya girik yang merupakan hasil fiscal cadaster. Dalam hal ini, fiscal cadaster tujuannya hanya mempermudah pungutan pajak tanah dan bukan untuk menerbitkan tanda bukti hak.

Kegiatan pendaftaran tanah selanjutnya diatur lebih lanjut dalam Peraturan Pemerintah No.24 Tahun 1997 yang merupakan hasil penyempurnaan dari Peraturan Pemerintah No.10 Tahun 1961, tercantum pada Pasal 19 dalam hal memberikan suatu hak baru atas tanah harus dibuktikan dengan akte yang dibuat oleh dan dihadapan penjabat yang ditunjuk oleh Menteri Agraria. Barangsiapa membuat akte yang terdapat dalam Pasal 19 tanpa ditunjuk oleh Menteri Agraria sebagai penjabat dapat dikenakan sanksi pidana. Maka, dapat dikatakan tidak ada satu pun instansi selain Badan Pertanahan Nasional (selanjutnya disebut "BPN") yang dapat menerbitkan tanda bukti hak. 
Sehingga sangat tepat putusan Mahkamah Agung yang mengadili membatalkan putusan Pengadilan Tinggi DKI yang menguatkan putusan Pengadilan Negeri Jakarta Barat, dengan pertimbangan bahwa Penggugat sekarang Termohon Kasasi tidak dapat membuktikan bukti yaitu sertipikat dan girik yang dimilikinya bukanlah surat bukti kepemilikan hak atas tanah.

\section{PENUTUP}

\section{A. Kesimpulan}

1. Status girik terkait pembuktian hak atas tanah dalam hukum tanah nasional, bahwa girik merupakan surat pajak hasil bumi sebelum lahirnya UUPA yang dianggap dalam kalangan masyarakat sebagai tanda bukti kepemilikan tanah, karena pengenaan pajak dikenakan pada yang memiliki tanahnya serta hal ini terbukti disebabkan sampai saat ini masih terdapat tanah bekas hak milik adat yang belum dikonversi setelah UUPA berlaku. Pentingnya pendaftaran hak milik adat atas tanah sebagai bukti kepemilikan atas tanah secara sah telah diatur sesuai dengan Pasal 23, Pasal 32, dan Pasal 38 UUPA. Serta tujuan pendaftaran telah diatur dalam Pasal 19 Ayat (1) UUPA untuk memberikan kepastian hukum. Maka, setelah lahirnya UUPA girik sudah tidak lagi dibuat namun keberadaannya masih diakui sampai dengan saat ini. Keberadaan girik sampai dengan sekarang, memiliki fungsi sebagai salah satu syarat pengkonversian tanah milik adat serta girik dapat disertakan sebagai salah satu syarat proses pendaftaran tanah khususnya dalam hal pembuktian hak lama sebagaimana diatur oleh PP No. 24 Tahun 1997 tentang Pendaftaran Tanah yang tercantum dalam Pasal 24 Ayat (1) dan Ayat (2).

2. Pertimbangan hakim Mahkamah Agung dalam memutus perkara sengketa perdata nomor $2459 \mathrm{~K} / \mathrm{Pdt} / 2014$ terkait penggunaan girik no.87 persil 157 kelurahan Cengkareng Barat, bahwa dalam putusan Mahkamah Agung tersebut mengadili sendiri yaitu membatalkan putusan Pengadilan Tinggi DKI yang telah memperbaiki amar putusan 
Pengadilan Negeri Jakarta Barat dengan pertimbangan bahwa Penggugat sekarang Termohon Kasasi tidak dapat membuktikan bukti yaitu sertipikat dan girik yang dimilikinya bukanlah surat bukti kepemilikan hak atas tanah merupakan putusan yang sangat tepat dikarenakan kelemahan Penggugat sekarang Termohon Kasasi yaitu tidak dapat membuktikan haknya dengan tanda bukti yang kuat yang disebut dengan sertifikat. Mengingat yang dipunyai Termohon Kasasi hanya girik yang merupakan hasil fiscal cadaster. Dalam hal ini, fiscal cadaster tujuannya hanya mempermudah pungutan pajak tanah dan bukan untuk menerbitkan tanda bukti hak.

\section{B. Saran}

1. Agar pemegang hak atas tanah lama terutama bekas hak milik adat yang alas haknya masih berdasarkan girik, sebaiknya segera melakukan penegasan konversi sehingga tanah tersebut berubah statusnya dari tanah hak milik adat menjadi tanah hak milik menurut UUPA. Disamping itu, agar pemegang hak mempunyai tanda bukti hak yang kuat yang dikenal dengan nama sertifikat.

2. Bahwa untuk mengurangi timbulnya kesalahpahaman yang dapat melahirkan sengketa tanah pada kemudian hari, maka diperlukan persamaan pemahaman tentang status girik sebagai hasil fiscal cadaster bukan sebagai legal cadaster.

\section{DAFTAR PUSTAKA}

\section{A. Buku}

Abdurahman. Himpunan Yurisprudensi Hukum Agraria. Seri Hukum Agraria VI. Bandung: Alumni, 1980.

Harsono, Boedi. Hukum Agraria Indonesia, Sejarah Pembentukan UndangUndang Pokok Agraria, Isi Dan Pelaksanaannya. Cetakan ke-1. Jakarta: Universitas Trisakti, 2013.

Perangin, Effendi. Praktek Pengurusan Sertifikat Hak Atas Tanah, Cetakan ke-2. Jakarta: Rajawali Pers, 1990.

Ruchiyat, Eddy. Politik Pertanahan Sebelum dan Sesudah Berlakunya UUPA, Cetakan ke-1. Bandung: Alumni, 1984. 
Saleh, K Wantjik. Hak Anda Atas Tanah. Cetakan ke-3. Jakarta Timur: Balai Aksara, 1980.

Santoso, Urip. Pendaftaran dan Peralihan Hak Atas Tanah. Cetakan ke-1. Jakarta: Kencana, 2010.

Sukamti, Abdurahman dan Arie. Tanya Jawab Masalah Pertanahan. Cetakan ke1. Jakarta: Sinar Harapan, 1985.

Sunindhia, Y.W dan Ninik Widiyanti. Pembaharuan Hukum Agraria (Beberapa Pemikiran). Cetakan ke-1. Jakarta: PT Bina Aksara, 1988.

Sutedi, Adrian. Peralihan Hak Atas Tanah Dan Pendaftarannya. Cetakan ke-4. Jakarta: Sinar Grafika, 2010.

2014. . Sertifikat Hak Atas Tanah. Cetakan ke-3. Jakarta: Sinar Grafika,

B. Peraturan Perundang-undangan

Indonesia. Undang-Undang Dasar Negara Republik Indonesia Tahun 1945. Undang-Undang Nomor 5 Tahun 1960 tentang Peraturan Dasar Pokok- Pokok Agraria (Lembaran Negara Republik Indonesia Tahun 1960 Nomor 104, Tambahan Lembaran Negara Republik Indonesia Nomor 2043).

C. Jurnal

Handayani, Sri dan Pius Tri Wahyudi Soehartono. "Pendaftaran Hak Atas Tanah Letter C, Girik dan Petuk D Sebagai Alat Bukti Permulaan Di Kabupaten Sleman Daerah Istimewa Yogyakarta". Jurnal Repertorium, Edisi No.2, (Juni 2015): 127.

Hasanah, Ulfia. "Status Kepemilikan Tanah Hasil Konversi Hak Barat Berdasarkan UU No.5 Tahun 1960 Tentang Peraturan Dasar Pokok-Pokok Agraria Dihubungkan Dengan PP No.24 Tahun 1997 Tentang Pendaftaran Tanah”. Jurnal Ilmu Hukum. Volume.3, Nomor 1, (Juni 2005): 2.

D. Putusan Pengadilan

Indonesia. Putusan Pengadilan Negeri Jakarta Barat Nomor: 210/Pdt.G/2013/PN.JKT.BAR.

. Putusan Pengadilan Tinggi DKI Nomor: 223/PDT/2014/PT.DKI.

E. Skripsi

Putusan Mahkamah Agung Nomor: 2459K/PDT/2014.

Astrid, Adelia. "Pendaftaran Pertama Kali Untuk Konversi Tanah Hak Milik Karena Pewarisan Melalui Kegiatan Layanan Rakyat Untuk Sertipikasi tanah (Larasita) Dalam Rangka Mewujudkan Tertib Administrasi Pertanahan Berdasarkan PP Nomor 24 Tahun 1997 Juncto Peraturan Kepala BPN Nomor 18 Tahun 2009 Di Kabupaten Boyolali”. Skripsi. (Yogyakarta: UAJY, 2011). 